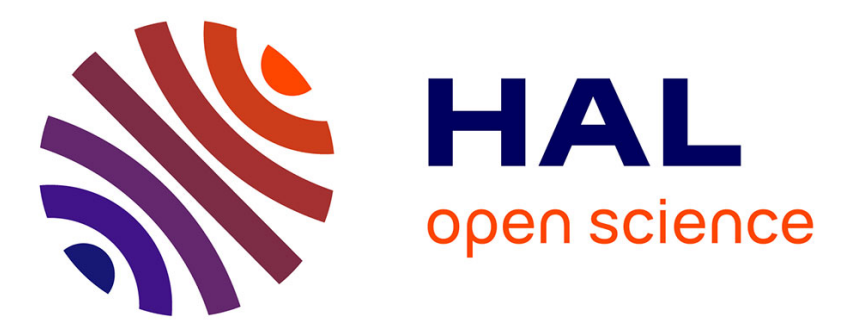

\title{
Tolerance and efficacy of a polyamine-deficient diet for the treatment of perioperative pain
}

Jean-Pierre Estebe, Cécile Degryse, Gilles Rezzadori, Florin Dimache, Georges Daccache, Alain Le Naoures, Anissa Belbachir, Pierre Schoeffler, Anne-Laure Sérandour

\section{To cite this version:}

Jean-Pierre Estebe, Cécile Degryse, Gilles Rezzadori, Florin Dimache, Georges Daccache, et al.. Tolerance and efficacy of a polyamine-deficient diet for the treatment of perioperative pain. Nutrition, 2016, In press. 10.1016/j.nut.2016.02.018 . hal-01290418

HAL Id: hal-01290418 https://hal-univ-rennes1.archives-ouvertes.fr/hal-01290418

Submitted on 3 May 2016

HAL is a multi-disciplinary open access archive for the deposit and dissemination of scientific research documents, whether they are published or not. The documents may come from teaching and research institutions in France or abroad, or from public or private research centers.
L'archive ouverte pluridisciplinaire $\mathbf{H A L}$, est destinée au dépôt et à la diffusion de documents scientifiques de niveau recherche, publiés ou non, émanant des établissements d'enseignement et de recherche français ou étrangers, des laboratoires publics ou privés. 
Title: Tolerance and efficacy of a polyamine-deficient diet for the treatment of perioperative pain.

Abbreviated Title: Polyamine-deficient diet.

Authors: Jean-Pierre Estebe ${ }^{1}$; Cécile Degryse ${ }^{2}$; Gilles Rezzadori ${ }^{3}$; Florin Dimache ${ }^{4}$; Georges Daccache $^{5}$, Alain Le Naoures ${ }^{1}$, Anissa Belbachir ${ }^{6}$, Pierre Schoeffler $^{7}$, Anne-Laure Sérandour ${ }^{8}$

Correspondence to: Jean-Pierre Estebe MD, $\mathrm{PhD}$

Department of Anesthesiology, University Hospital of Rennes

Rue Henri Le Guilloux 35033, Rennes, France

Email: jean-pierre.estebe@ @ chu-rennes.fr

Phone: + 33668983383

Summary statement: Suppression of polyamines from the diet offers a nutrition-based treatment option for perioperative pain reduction.

\section{Authors:}

${ }^{1}$ Department of Anesthesiology, University Hospital of Rennes, 2 rue Henri le Guilloux 35033 Rennes, France: Jean-Pierre Estebe MD, PhD; Alain LeNaoures MD: alain.lenaoures@chu-rennes.fr

${ }^{2}$ Department of Anesthesiology, University Hospital Pellegrin of Bordeaux, Place Amélie Raba-Léon 33076 Bordeaux, France: Cecile Degryse MD: cecile.degryse@ chu-bordeaux.fr ${ }^{3}$ Department of Anesthesiology, University Hospital Pasteur of Nice, 30 avenue de la Voie Romaine 06000 Nice, France: Gilles Rezzadori MD: rezzadori.g@chu-nice.fr ${ }^{4}$ Department of Anesthesiology, University Hospital Hautepierre of Strasbourg, 1 avenue Molière 67200 Strasbourg, France: Florin Dimache MD: florin.dimache@chru-strasbourg.fr ${ }^{5}$ Department of Anesthesiology, University Hospital of Caen, Avenue Côte de Nacre 14050 Caen, France: Georges Daccache MD: daccache-g@ chu-caen.fr

${ }^{6}$ Department of Anesthesiology, University Hospital Cochin, 27, rue du Faubourg St Jacques 75014 Paris, France: Anissa Belbachir MD: anissa.belbachir@cch.aphp.fr

${ }^{7}$ Department of Anesthesiology, University Hospital Gabriel Montpied of Clermont-Ferrand, 58 rue Montalembert 63003 Clermont-Ferrand, France: Pierre Schoeffer MD: pschoeffler@chu-clermontferrand.fr 
8 - SLB Pharma, 28 bis rue du Thabor 35000 Rennes, France: Anne-Laure Serandour: al.serandour@slbpharma.com

Institutional Review Board: Comité de protection de personnes Ouest VI: Centre hospitalier Universitaire Cavale Blanche; Avenue Tanguy Prigent; 29609 Brest Cedex France. Chair Doctor Mariannick Le Bot. CPP Ouest 6-592; ref file: NTL_RACHIS_09/2ALGIE1. Number EudraCT: 2009-A00504-53. Email address: cpp.ouest@ chu-brest.fr. Fax: +33298342579. Phone +33298342580

CPP Ouest VI: CHU Cavale Blanche; Avenue T Prigent; 29609 Brest Cedex France. CPP Ouest 6-592; ref file: NTL_RACHIS_09/2ALGIE1. Number EudraCT: 2009-A00504-53. cpp.ouest@chu-brest.fr

Abstract: 259 words

Introduction: 480 words

Conclusion: 1162 words

Key words: polyamines, diet, pain, perioperative pain, spine surgery, NMDA receptors. Conflict of interest: Jean-Pierre Estebe had a patent from the University of Rennes 1 (07703762.02114 PCT/EP2007050215; European Patents 1973425B1; 10.03.2010) and is a shareholder in Nutrialys Medical Nutrition SA. He was in charge of designing the study protocol but did not participate as an investigator in the study and did not contribute to the recording of the data or the statistical evaluation.

Funding: The study was supported by Nutrialys Medical Nutrition SA. The sponsor was not involved in the design of the study, data analysis, data interpretation, or the writing of the clinical report. They also did not have access to the clinical trial database. The corresponding author had full access to all of the data in the study and had final responsibility for the decision to submit the report for publication.

Highlights: Polyamines diet offers a nutrition-based treatment option for perioperative pain reduction. 
Abstract:

Background: Polyamines have been identified as pain agonists and interact with NMDA receptors. A prospective, randomized, multicenter, and blinded phase II clinical trial was conducted to evaluate a polyamine-deficient diet for the treatment of perioperative pain in patients during spinal surgery.

Material and Methods: All analyses followed the intention-to-treat principle. The trial was designed to evaluate the dose-ranging effect of a low polyamine diet with respect to a total (group 1) or partial (group 2) polyamine diet on perioperative pain (7 days before and 5 days after surgery). Pain (numerical scale at rest and motion), Quality of life questionnaires (Brief Pain Inventory, EIFEL questionnaire, and Short Form-12 acute questionnaire), and tolerance of and compliance with the nutritional program were measured.

Results: Compliance (preoperatively: $100 \%$ in group 1 and $83 \%$ in group 2; postoperatively: $83 \%$ in group 1 and $71 \%$ in group 2) and tolerance were good. After seven days of the diet before surgery, a trend of decrease on pain was observed in group 1 whereas no effect was observed in group $2(P=0.144)$. This analgesic effect became significant in group 1 in the subgroup of patients with initial high levels of pain $(\mathrm{NS} \geq 4)$ at rest $(P=0.03)$. and on motion $(P=0.011)$. Quality of life was significantly improved in group $1(P=0.0465)$. In the postoperative period, pain was significantly decreased in group 1 compared to group 2 at rest $(P=$ 0.022). and on motion $(P=0.029)$. The effect was significantly better on patients with higher initial pain both at rest $(P=0.013)$ and on motion $(P=0.005)$ in group 1 compared to group 2.

Conclusion: Suppression of polyamines from the diet offers a nutrition-based treatment option for perioperative pain reduction independent of and complementary to typical analgesic approaches. 


\section{Introduction:}

Lower back pain, with or without leg pain, is a notably common problem that effects up to $85 \%$ of adults and has a negative impact on work productivity and quality of life $\mathrm{e}^{1-2}$. It may lead to a history of pain sensitization and long-term use of pain medication. Lumbar spinal stenosis surgery (LSS) is a perfect surgical example of the complex situation when nociceptive (i.e., low back pain), inflammatory (i.e., articular hypertrophy), and neuropathic pain (i.e., neurogenic pain) combine to result in substantial psychological and/or social consequences $^{3}$. In this case, the postoperative outcomes remain partially satisfactory (i.e., persistent chronic postoperative pain) ${ }^{4}$.

Excitation of N-methyl-D-aspartate (NMDA) receptors was considered a straightforward process that evolved to maximize the rate of neuronal communication. It was recently reported that NMDA receptors might play an important role in pain and/or hyperalgesia phenomena, particularly in pain memorization and pain sensitization. In a recent review, it was reported that ketamine has an opioid sparing effect, particularly in painful procedures $^{5}$, that is mainly due to the inhibition of NMDA receptors ${ }^{6}$. Many different NMDA receptor subtypes coexist in the central nervous system ${ }^{7}$. Usually localized in postsynaptic sites, they are mobile with various levels of conductance channels modulated by protons, polyamines (PA), and magnesium.

PA (putrescine, spermidine, and spermine) are ubiquitous small cationic organic molecules ${ }^{8}$. They contribute to the control of neuronal excitability. PA act on tyrosine phosphorylation of NMDA receptor subtype-2B as a scaffolding element of neuroplasticity ${ }^{7}$. PA have been intensively investigated, and their link to several pathologies has been well established ${ }^{8}$. In addition to their well-known universal role in cell division and proliferation, PA are involved in additional biological processes, such as tumor growth ${ }^{9}$ and inflammatory processes ${ }^{10}$. Interesting preliminary clinical results were recently described in the treatment of the prostate cancer ${ }^{11-12}$. PA were recently shown to regulate the formation of mRNA stress granules $^{13}$. Apart from being endogenously synthesized, an exogenous supply of PA by intestinal uptake is generally assumed to be the predominant PA transport pathway. PA intestinal absorption occurs through dietary sources (80\%) and intestinal absorption from bacterial metabolism ${ }^{14-15}$. Because intestinal absorption is a critical source of PA, an obvious link between food and PA concentration has been suggested. Based on recent animal studies, researchers have proposed that certain "Functional Foods" (defined as foods or food components that may provide health benefits beyond traditional nutrition) may represent a promising and safe strategy for improving the management of pain in combination with 
analgesic drugs classically used ${ }^{16}$. However, establishing such a proof of concept in humans has never been specifically considered and in particular for perioperative pain. In a previous experimental model, it was reported that a polyamine-deficient diet (PDD) had preventive properties against pain hypersensitivity ${ }^{17}$, oxaliplatine-induced sensory neuropathy ${ }^{18}$, and had a curative effect on heroin-induced hyperalgesia in a rat model ${ }^{19}$.

To test the hypothesis that a PDD could have an effect on perioperative pain in humans, we designed a study by building on the experience gained in clinical trials on prostate cancer treatment ${ }^{11-12}$. We planned a prospective, randomized, multicenter, and blinded phase II clinical trial following the intention-to-treat principle with the pain level as primary endpoint. 


\section{Material and Methods:}

\section{Study design and patients:}

The study design was built on previous clinical observations made with patients suffering from chronic non-malignant pain ${ }^{20}$ and in castrate-resistant prostate cancer ${ }^{12}$. A significant decrease in the pain scores was observed when patients were under strict PDD, i.e., $80 \%$ of the food intake calories were provided by the food for special medical purposes, specifically Polydol $^{\mathrm{TM}}$, which is characterized by a low PA content. Conversely, no effect on pain was observed when patients were only under partial PDD. This lack of efficacy was probably due to an insufficient systemic depletion of PA. So, we consider that partial PDD could be used as control group. In the aim to obtain a blinded effect and to avoid some placebo effects, patients were informed that it was a dose-ranging study. So, in partial PDD group, patients could expect a significant analgesic effect with less inconvenient than in strict PDD group.

This prospective, randomized, multicenter, blinded phase II study was designed to evaluate the dose-ranging effect of a low PA diet with respect to a total (less than $10 \mu \mathrm{mol}$ of PA / day) or partial (approximately $370 \mu \mathrm{mol}$ of PA / day) PA diet on perioperative pain.

Eligible patients were aged 18 years or older and had chronic low back pain scheduled for spine surgery. The exclusion criteria were undernutrition, major medical problems, participation in another randomized trial, inability to use a patient controlled analgesia (PCA) morphine, or an inability to provide written informed consent. Patients using NSAIDs and steroids for other spine-related reasons, or nefopam were excluded. Pregnancy and diabetes with inadequate glycemic control were also exclusion criteria.

This study was conducted in accordance with the principles of the Declaration of Helsinki (59 $9^{\text {th }}$ general assembly of the WMA, Seoul, South Korea, October 2008), the Directive 2001/20/EC of the European Parliament and of the Council and the French principles of good clinical practices. The study was approved by AFSSAPS and by the Regional French Ethics Committee (ID-RCB: 2009-A00504-53 August 2009). The design and description of the study adhered to the guidelines of the CONSORT (Figure 1). All patients provided written informed consent for trial participation.

\section{Randomization:}

Eligible patients were randomly assigned (1:1) to group 1 or group 2 at least 10 days before spinal surgery. Block randomization of 16 patients was used to assign patients and was 
prepared and coordinated by an independent contract research organization (SLB Pharma, 28 bis rue du Thabor, 3500 Rennes France). The allocation sequence was computer-generated by the trial center. Only the physicians were aware of the treatment assignment.

\section{Treatment:}

Diet:

Polydol $^{\mathrm{TM}}$ is a food for special medical purposes according the European directive 1999/21/CE and was provided by Nutrialys Medical Nutrition SA. Each $250 \mathrm{ml}$ drink contains a very low content of PA (less than $0.1 \mu \mathrm{mol}$ of PA / drink). The nutritional information of Polydol ${ }^{\mathrm{TM}}$ is given in Table 1.

In the total PDD group (group 1), 6 drinks provided $1600 \mathrm{Kcal} /$ day and additional 450 kcal were provided by a European breakfast (100 g of white bread, $100 \mathrm{ml}$ of milk, $10 \mathrm{~g}$ of butter, and $10 \mathrm{~g}$ of sugar or jam). The patients could ingest additional drinks if they felt still hungry. In the partial PDD group (group 2), patients completed their normal diet with two drinks/day whenever necessary. The diet started 7 days before surgery and continued for 5 days after surgery. Nutrialys Medical Nutrition SA performed home and hospital pharmacy deliveries.

\section{Surgery:}

The surgical solution is to decompress the stenotic part of the lumbar spine. In cases of spine instability, one or more posterior lumbar interbody arthrodeses or fusions could be performed (restricted to four levels or less). Procedure-related complications such were recorded.

\section{Anesthesia:}

Before anesthesia, regular treatments were not modified. Regarding the intervention, each center was allowed to adopt its own anesthesia procedures, but due to the potential action on NMDA receptors, nitrous oxide, nefopam, and ketamine were contraindicated. To control postoperative pain, intravenous morphine PCA pumps were used by the patients according to a standardized protocol (i.e., bolus dose: $1 \mathrm{mg}$ of morphine, lockout interval: 5 min; without maximal dose). Of course, usual multi modal analgesia protocol was systematically applied (paracetamol, NSAID) at the end of the surgery and during the postoperative period. 


\section{Assessments and follow-up:}

All parameters were recorded at each visit: i.e., at the inclusion time V0 (= preanesthesia visit) before diet, after 7 days of the diet just before surgery (V1), the day after surgery (V2), 5 days after surgery at the end of the diet (V3), and 1 and 6 months after the surgery (V4 and V5, respectively) (Figure 2).

Compliance was recorded on each patient's block note and was considered good if the patient consumed more than 5 drinks/day in group 1 and more than 1.5 drink/day in group 2 (i.e., $80 \%$ of the total theoretical dose in each group). The tolerability was periodically evaluated based on the reporting of adverse effects (AEs) for all participants (i.e. nausea, vomiting, and diarrhea or constipation) considered as minor AEs if they do not require treatment, and major AEs if specific treatment was required.

The primary endpoint of the study was the pain level, evaluated by the numerical scale (NS) (zero to 10) at rest just after surgery (V2). But at each step pain at rest and at motion was recorded.

The major secondary endpoint was the tolerance to the PDD. The other secondary endpoints were neuropathic pain evaluated by the DN4 questionnaire and Neuropathic Pain Symptom Inventory (NPSI) questionnaire. Quality of life was determined using the Brief Pain Inventory (BPI), EIFEL questionnaire (French version of Low Back Pain and Disability questionnaire), Short Form-12 (SF-12) acute questionnaire; sleep disorders were evaluated based on the NS of sleepiness (from 0 good sleep to 10 worst sleep disorder).

\section{Statistical analysis:}

All analyses followed the intention-to-treat (ITT) principle. On the ITT, a sample size of 64 patients (i.e., $\mathrm{n}=32$ in each group) had been determined to produce $80 \%$ power to detect a significance in the rate of pain at $\alpha=0.05$ (two-tailed), assuming that the pain decrease was 1 point (V0 Vs. V2). Due to the lack of preliminary data, we made the hypothesis that PDD, as MNDA antagonist, had a similar effect as another NMDA antagonist reported in the literature (ketamine $)^{21}$. The description of the ITT population was based on the comparison of the means of quantitative variables or proportions of qualitative variables between 2 independent groups. All tests were two-tailed with significance at $5 \%$.

For quantitative variables, the results are expressed as the mean with standard deviation (SD), range and average. Conditions of validity when using parametric tests were checked systematically. Shapiro-Wilk test assessed whether variable distributions violated the assumption of normality. Student's test (T test) was used and was matched (T test) for 
comparison of means between two independent groups and matched data, respectively. For the comparison of means from more than two groups, repeated measures with ANOVA method, followed by multiple comparisons based on the contrast method were used. When conditions of validity were not verified, Wilcoxon and Mann-Whitney non-parametric tests were used. Chi ${ }^{2}$ test or Fisher's exact test were used for comparison of proportions between two independent groups, and McNemar test was used for matched data. A post-hoc analysis with the level of preoperative pain (groups with or without numerical scale of pain $\geq 4$ ) was performed based on the hypothesis that high level of pain induced more hyperalgesia phenomenon.

Statistical analysis was accomplished using JMP software from SAS Institute (10.0 version for Windows XP). $P<0.05$ is considered statistically significant. Data have been computed and double-checked by SLB Pharma, and decisions regarding exclusions of patients from the statistical analysis were made with the principal investigator. 


\section{Results:}

Between September 2009 and September 2012, 64 patients recruited by seven participating hospitals were randomized. After the exclusion of 2 patients (one patient withdrew consent before treatment in group 1 and one withdrew for cancelled surgery due to cancer diagnosis in group 2), 60 patients were analyzed in ITT (one patient in each group was excluded from the ITT analysis because of the use of steroids) (Figure 1).

\section{Preoperative period}

\section{1.a. Before diet (V0)}

All characteristics of the patients were similar in group 1 and group 2 (Table 2). In each group, pain on motion was significantly higher than pain at rest $(P<0.0001)$. More than $80 \%$ of the patients were taking pain medication on a regular basis before surgery with no significant difference between both groups. More than $50 \%$ of these patients were taking step I pain medication according to the WHO-pain ladder (non-opioid medication). Twenty-six patients (52\% vs. $46 \%$ for groups 1 and 2, respectively) received step II pain medication and 5 patients received step III pain medication. Despite the possible implication of the number of pain medications used on pain levels, there was no significant correlation in each group between the number of their medications and the level of pain (no treatment: $n=9$ (at rest NS $=3.7 \pm 2.6)$, one treatment: $\mathrm{n}=21(\mathrm{NS}=4.0 \pm 2.3)$ and more than one treatment: $\mathrm{n}=30$ (NS $=4.7 \pm 2.3)$ ). There was only a slightly non-significant higher level of pain for patients on opioid medications ( $\mathrm{n}=5, \mathrm{NS}=5.2 \pm 2.2$ at rest, and $7.4 \pm 1.3$ on motion). There was no difference in neuropathic pain characteristics and in the results of quality of life questionnaires.

\section{1.b. Preoperative effects of the PDD (V1).}

The compliance was $100 \%$ in group $1(n=30 / 30)$ and $83 \%(n=24 / 29)$ in group 2 (Table 3). The tolerance was good. A few minor AEs (not requiring treatment) were recorded in group 1 than in group 2 were reported (nausea 9 vs. 4; constipation 6 vs. 2, diarrhea 6 vs. 2; for group 1 and 2, respectively). No additional drinks were used, and only $15 \%$ of patients required rice or bread at least once to be satiated in group 1.

In group 1, after seven days of PDD and without any change in analgesic treatment, there is a non-significant decreasing trend of their pain at rest $(4.0 \pm 2.7$ to $3.5 \pm 2.5$ at $\mathrm{V} 0$ and $\mathrm{V} 1$, respectively) and on motion ( $6.7 \pm 2.5$ to $5.7 \pm 2.8$ for V0 and V1, respectively). No similar effect was observed in group 2. Based on previous clinical results showing that the 
patients who had higher levels of pain were experiencing more decreased pain after a PDD, the evolution of pain in patients with NS $\geq 4$ at V0 $(n=18$ and 21 at rest, and $n=29$ and 26 on motion, in group 1 and 2, respectively) was explored. In group 1, pain at rest decreased significantly from $5.9 \pm 1.4$ at V0 to $4.5 \pm 2.6$ at V1 $(P=0.03)$ and pain on motion decreased significantly from $7.2 \pm 1.8$ at V0 to $5.8 \pm 2.8$ at V1 $(P=0.011)$. In group 2, there was no difference in the pain levels for the patients with a NS $\geq 4(P=0.75$ at rest and $P=1$ at motion).

The opioid treatment did not influence those results and no significant difference was observed when the patients $(n=5)$ with opioid medication were excluded from the statistical analysis.

After seven days of the diet, the quality of life according to the EFEIL questionnaire was significantly improved in the total PDD group $1(P=0.046)$.

\section{Per-operative period (day 0).}

Pre-operative characteristics were similar for all of the patients (see table 4). Five patients in group $1(16 \%)$ and four patients in group 2 (14\%) underwent unintended durotomy.

Despite their contraindication in the protocol, two patients in each group received an anti-NMDA drug (one patient received nitrous oxide administration and one received nefopam in group 1; two patients received ketamine administration in group 2). Multimodal pain treatment was almost used systematically and in the same way for all of the patients. Anesthesia protocols were similar in the two groups.

\section{Postoperative period}

3.a. Immediate postoperative period (day 1 (V2) to day 5 (V3) after surgery)

Twenty-seven and twenty-six patients remained under protocol in groups 1 and 2, respectively at V2, and twenty-four and twenty-five patients at the end of the diet (V3).

During the postoperative period, compliance with the diet remained satisfactory until the end of the diet at day 5 (Table 3). As preoperatively, there were slightly more minor AEs in group 1 than in group 2. However, more patients needed a specific treatment in group 2 (4 vs. 7, in groups 1 and 2, respectively).

At V2, one day after the surgery, pain at rest was significantly decreased in group 1 compared to group $2(P=0.022$, Table 5) as expected in our statistical design. Regarding pain on motion, the decrease of pain between the two groups did not reach significance; but there 
was a significant decrease of pain in group $1(6.7 \pm 2.5$ at V0 to $5.1 \pm 2.9$ at $\mathrm{V} 2 ; P=0.029)$, whereas no such effect was recorded in group 2.

When the evaluation was performed for the patients with higher pain at rest (NS $\geq 4$ at V0), the effect of group 1, in comparison with group 2 , was more significant at rest $(P=$ $0.013)$ as well as on motion $(P=0.005)$. The decrease of pain on motion was clearly significant in group $1(P=0.004)$, whereas no significant effect was observed in group $2(P=$ 1). ANOVA analysis (V0 to V2) confirmed the interaction between the level of pain (NS< 4 or NS $\geq 4$ at V0) and the treatment $(P=0.001)$.

At the end of the nutritional program (V3) just before leaving the hospital and, likely because of the impact of the surgery, the level of pain was similar in both groups.

In terms of the quality of life and because of the difficulties in performing an evaluation on the first postoperative day, we only made a comparison at V3. Although significance was not reached, we found a trend of improvement in group $1(P=0.063)$ with the EFEIL questionnaire.

There was no difference in the postoperative opioid and non-opioid analgesic consumption (Table 6).

Long-term follow-up (at 1 (V4) and 6 months (V5))

There was no difference between the two groups in terms of postoperative hospital length of stay. One patient in each group had a new hospitalization between V3 and V4, one in group 1 for scar infection and one in group 2 for surgical complication, and during the six months following surgery (for new disc herniation). Despite of the positive effects of PDD in perioperative situation, there was no difference between the two groups in terms of long-term outcomes. 


\section{Discussion:}

We found that the PDD using Polydol ${ }^{\mathrm{TM}}$ had pain reduction effects on perioperative (i.e., pre and early postoperative) pain in the current clinical study. This is the very first randomized multicenter clinical trial confirming this new approach for the management of chronic pain. Our clinical data reinforce results from previously reported preliminary studies $^{12,20}$. We choose to use a control group with partial PDD because we known that a partial PDD is not enough to induce a sufficient decrease of PA to allow a clinical effect. It was only reported an effect in chronic pain when a profound PA diet was previously induced. A group eating just a regular diet could be disappointed and we could not extrapolate the placebo effect.

Despite the multicenter design study, the two groups were similar enough to provide a statistical evaluation. The mean duration of pain before surgery was approximately two years confirming the patient's status of chronic pain.

Covariate analysis, using ANOVA analysis, led to the observation that males had significantly less pain at rest than females $(P=0.014$ at V0) so it was not surprising that the effect of the diet was more significant in the female group ( $P=0.011$ at V2 compared to V0) than in males $(P=0.06)$. These differences were not significant on motion. Note that the gender difference was previously reported with various explanations $\left[\mathrm{see}^{22}\right]$.

It is noteworthy that pain reduction induced by PDD was relatively quick with a significant effect reported during the preoperative period (7 days) despite any therapeutic modification. Interestingly, this PA deficient diet seems to be more effective for the higher levels of pain. If the statistical significance was not reached during the preoperative period, it is noteworthy that the decrease of pain was 0.5 points at rest and 1.0 point on motion in group 1 , whereas no effect was recorded in group 2 . If we evaluate patients with higher pain (NS $\geq 4$ at rest) at V0, before surgery the effect of PDD led to a decrease 1.4 points at rest, and on motion. In other words and as an example, on motion if more than $90 \%$ of patients in the two groups had high levels of pain on motion ( $\mathrm{NS} \geq 4$ ) at $\mathrm{V} 0$, we observed a decrease at $70 \%$ before surgery to 54\% just after surgery and 35\% at the end of the nutritional program in group 1; whereas it remains at $90 \%$ at V1, 87.5\% at V2 and 54\% at V3 in group 2. In group 1, the pain reduction effect observed during the preoperative period was significantly increased just after surgery. On the one hand, it was reported in the literature that there was a clear correlation between the level of the preoperative pain and the level of postoperative pain ${ }^{23}$. On the other hand, the level of postoperative pain is predictive of chronic pain ${ }^{4}$. Therefore, the 
efficacy of the PDD during the preoperative period could be very important. Quality of life was significantly improved during the preoperative diet treatment. Using the BPI questionnaire, we found no benefit; however, this may be because the questions refer to an assessment throughout this week of treatment. To see an effect of the treatment, BPI questions should have been asked just during the last two days.

The compliance with the PA deficient diet was very good, with no indication of significant food related AE. The relatively short duration of participation in the PDD (12 days) was accomplished by all our patients with a high frequency of compliance. The good tolerance could also be explained by prevention or treatment of anxiety, as previously described in a rat model ${ }^{24}$ and with other NMDA antagonists ${ }^{25,26}$. Preoperatively, the trend of decreased pain and the significant improvement of quality of life could also impact patient's psychology and may explain the better compliance observed in group 1. Due to the design of the study (dose-ranging study) we could most likely exclude a psychological effect between the two groups as usually observed if the patient information uses words such as placebo or control group. PDD, with appropriate composition of food, seems to have no AE on a postoperative period in terms of wound healing or risk of infection.

Due to the design of this clinical study, the number of patients included may have been too small to reach a level of significance with regard to long-term follow-up. Nevertheless, it was not surprising that no significant effects were recorded at 1 and 6 months. In previous clinical trials, the effects were more significantly prolonged when the duration of the total PDD was extended by more than 2 weeks. As described in prostate cancer publications and unpublished data on chronic pain treatment ${ }^{12,20}$, prolonged pain reduction effect has been maintained after 3 weeks of total PDD by the polyamine relative diet. Patients progressively modified the diet with foodstuff as a function of their PA content and decreased the number of drinks per day moving to a diet based on a list of foods with low PA content. Using a polyamine database, we could introduce diet variations based on the estimation of PA exposure $^{27-29}$.

If the major mechanism of action of PDD is most likely due to an inhibition of tyrosine phosphorylation of the NMDA receptors, we could not exclude other mechanisms of action. PA levels generally increase with inflammation. These higher levels and activity lead to the influx of pro-inflammatory macrophages into the central nervous system. We could not exclude a peripheral effect because experimental data have shown that peripheral PA are related to the induction of inflammation which is reduced with the inhibition of the PA biosynthesis enzyme ${ }^{15}$. This is consistent with recent publications in the prevention of 
colorectal adenoma $^{30-31}$. In addition to NMDA receptors, PA may interact with different affinities with the voltage sensitive calcium channel, TRPV1, or AMPA. In the absence or decrease of extracellular PA, there may be a decrease of intercellular PA movement, which would decrease the stress response, or there is a more efficient intercellular PA migration producing a better coordinated response to stress and cell proliferation ${ }^{13}$. Nevertheless, the possible anti-inflammatory effect displays no significant adverse effects during the postoperative period. As previously mentioned, we did not observe any delay in wound healing or level of infection. Most likely, the PA deficiency is not substantial enough to depress the wound healing processes, which may be because quiescent cells have a significant lower PA content than active cells, quiescent cells are less sensitive to many stresses. However, with various possible mechanisms of action, there is emerging evidence indicating a relationship between PA and pain or neural sensitization emphasizing the importance of $\mathrm{PDD}^{17-19}$.

Some limitations of this study need to be addressed. We did not evaluate PA concentrations in the blood during the nutritional program. The development of an accurate biomarker of dietary PA exposure would improve the accuracy of PDD. We have previously reported a link between pain and the level of PA in the cerebrospinal fluid; but the biomarker was not yet accurately validated ${ }^{32}$. Particularly in the partial PDD group, the caloric load was not strictly controlled. Perhaps we could not exclude that caloric and type of calories introduce some differences. A true control group, with the same number of blinded drinks, could be discussed, but the procedure was too expensive. 
In conclusion, based on the current study, suppression of polyamines from the diet may be an important mechanism of preoperative and/or early postoperative (hyperalgesia) reduction independent of usual analgesic approaches. With good tolerance and compliance, a polyamine-deficient diet could be a new and safer technique for the treatment and/or the prevention of postoperative pain. Due to active patient participation, a polyamine diet could be part of the therapeutic education of chronic pain patients or be part of pre-habilitation strategy before surgery. This very first study confirms the concept proof the potential interest to use the polyamines diet as new analgesic strategy. Further studies must confirm the interest of such protocol for patients with high level of pain or for patients opioid-tolerant; comparison of the long-term benefits and costs will therefore require further studies. 


\section{References:}

1. Freburger JK, Holmes GM, Agans RP, Jackman AM, Darter JD, Wallace AS, Castel LD, Kaisbeek WD, Carey TS. The rising prevalence of chronic low back pain. Arch Intern Med 2009; 169: 251-8

2. Taylor VM, Deyo RA, Cherkin DC, Kreuter W. Low back pain hopitalization. Recent United States trends and regional variations. Spine 1994; 19: 207-13

3. Gerbershagen HJ, Aduchathil S, van Wijck AJM, Peelen LM, Kalkman CJ, Meissner W. Pain intensity on the first day after surgery: A prospective cohort study comparing 179 surgical procedures. Anesthesiology 2013; 118: 934-44

4. Robinson Y, Michaelsson K, SandenB. Instrumentation in lumbar fusion improves back pain but not quality of life 2 years after surgery. Acta Orthop 2013; 84: 7-11

5. Laskowski K, Stirling A, McKay WP, Lim HJ. A systematic review of intravenous ketamine for postoperative analgesia. Can J Anesth 2011; 58: 911-23

6. Weinbroum AA. Non-opioid IV adjuvants in the perioperative period: pharmacological and clinical aspects of ketamine and gabapentinoids. Pharm Res 2012; 65: 411-29

7. Paoletti P, Bellone C, Zhou Q. NMDA receptor subunit diversity: impact on receptor properties, synaptic plasticity and disease. Nat Rev Neursci 2013; 14: 383-400

8. Minois N, Carmona-Gutierrez D, Madeo F. Polyamines in aging and disease. Aging 2011; 3: 716-32

9. Quemener V, Blanchard Y, Chamaillard L, Havouis R, Cipolla B, Moulinoux JP. Polyamine deprivation: a new tool in cancer treatment. Anticancer Res 1994; 14: 4438

10. Silva MA, Klafke JZ, Rossato MF, Gewehr C, Guerra GP, Rubin MA, Ferreira J. Role of peripheral polyamines in the development of inflammatory pain. Biochem Pharmacol 2011; 82: 269-77

11. Cipolla BG, Havouis R, Moulinoux JP. Polyamine reduced diet (PRD) nutrition therapy in hormone refractory prostate cancer patients. Biomed Pharmacother 2010; 64: $363-8$

12. Cipolla B, Miglianico L, Bligny D, Artignan X, Abraham C, Moulinoux JP. Prostate cancer, a low polyamine diet and docetaxel. Oncology 2013; 15: 555-63

13. Li CH, Ohn T, Ivanov $\mathrm{P}$, Tisdale $\mathrm{S}$, Anderson $\mathrm{P}$. elF5A promotes translation elongation, polysome disassembly and stress granule assembly. PLoS One 2010: 5: e9942

14. Bardocz S, Duguid TJ, Brown DS, Grant G, Pusz A, White A, Ralph A. The importance of dietary polyamines in cell regeneration and growth. Brit J Nutr 1995; 73: $819-28$

15. Larqué E, Sabater-Molina M, Zamora S. Biological significance of dietary polyamines. Nutrition 2007; 23: 87-95

16. Bell RF. Food and pain: should we be more interested in what our patient eat? Pain 2007; 129: 5-7

17. Rivat C, Richebe P, Laboureyras E, laulin JP, Havouis R, Noble F, Moulinoux JP, Simonet G. Polyamine deficient diet to relieve pain hypersensitivity. Pain 2008; 137: 126-37

18. Ferrier J, Bayet-Robert M, Pereira B, Daulhac L, Eschalier A, Pezet D, Moulinoux JP, Balayssac D. A polyamine-deficient diet prevents oxaliplatin-induced acute sensory neuropathy in rats. PLos One 2013; 8: e77828 
19. Le Roy C, Laboureyras E, Laulin JP, Simonet G. A polyamine-deficient diet opposes hyperalgesia, tolerance and the increased anxiety-like behaviour associated with heroin withdrawal in rats. Pharmacol Biochem Behav 2013; 103: 510-9

20. Moulinoux JP, Rivat C, Havouis R, Estebe JP, Legay F, Laulin F, Noble G. Polyamine deficient diet against pain. Gordon Research Conference (GRC) 2005; Boston USA

21. Remérand F, Le Tendre C, Baud A, Couvret C, Pourrat X, Favard L, Laffon M, Fusciardi J. The early and delayed analgesic effects of ketamine after total hip arthroplasty: a prospective, randomized, controlled, double-blind study. Anesth Analg 2009; 109: 1963-71

22. Mogil JS. Sex differences in pain and pain inhibition: multiple explanations of a controversial phenomenon. Nat Rev Neurosci 2012; 13: 859-66

23. Kalkman CJ, Visser K, Moen J, Bonsel GJ; Grobbee DE, Moons KG, Preoperative prediction of severe postoperative pain. Pain 2003; 105: 415-23

24. Pain L, Oberling P, Mainsongeon M, Moulinoux JP, Simonet G. Delayed aversive effects of high-dose fentanyl. Prevention by a polyamine-deficient diet. Behav Brain Res 2008; 190: 119-23

25. Riaza Bernudo-Soriano C, Perez-Rodriguez MM, Vaquero-Lorenzo C, Baca-Garcia E. New perspectives in glutamate and anxiety. Pharmacol Biochem Behav 2011; 100: 2217-28

26. Autry AE, Adachi M, Nosyeva E, Na ES, Los MF, Cheng PF, Kavalati ET, Monteggia LM. MNDA receptor blockade at rest triggers rapid behavioral antidepressant responses. Nature 2011; 475: 91-5

27. Cipolla BG, Havouis R, Moulinoux JP. Polyamine contents in current foods: a basis for polyamines reduced diet and a study of its long term observance and tolerance in prostate carcinoma patients. Amino Acids 2007; 33: 203-12

28. Soda K, Kano Y, Chiba F. Food polyamine and cardiovascular disease: an epidemiological study. Glob Health Sc 2012; 4: 170-8

29. Zoumas-Morse C, Rock CI, QuintanaEI, Neuhouser ML, Gerner EW. Meyskens Jr FL. Development of a polyamine database for assessing dietary intake. J Am Diet Assoc 2007; 107: 1024-7

30. Raj KP, Zell JA, Rock CL, McLaren CE, Zoumas-Morse C, Gerner EW, Meyskens FL. Role of dietery polyamnies in phase III clinical trial of difluoromethylornithine (DFMO) and sulindac for prevention of sporadic colorectal adenomas. Brit J Cancer 2013; 108: 512-8

31. Vargas AJ, Wertheim BC, Gerner EW, Thomson CA, Rock CL, Thompson PA. Dietary polyamine intake and risk of colorectal adenomatous polyps. Am J Clin Nutr 2012; 96: 133-41

32. Gentili ME, Estebe JP, Harvouis R, Cipolla B, Moulinoux JP, Ecoffey C.

Cerebrospinal fluid polyamine levels in patients with colonic disease. Reg Anesth Pain Med 2003; 28: 74-5 
Figure 1: Flow-chart of the study

Figure 2: Study design

Table 1: Nutritional information of POLYDOL ${ }^{\mathrm{TM}}$

Table 2: Preoperative characteristics and pain evaluation before the diet (V0) and after 7 days of the diet, before surgery (V1)

Table 3: Compliance with the diet at after 7 days (V1) and after 12 days (V3)

Table 4: Details of the surgery and anesthesia

Table 5: Postoperative characteristics and pain evaluation 1 day (V2) and 5 days (V3) after surgery

Table 6: Morphine consumption during and after surgery 
Designed the study and oversaw data collection and verification: JPE Enrolled patients and collected the data: CD, GR, FD, GD, AL, AB, PS, ALS

Analyzed and interpreted the data and wrote the initial draft: ALS, JPE

All authors critically ensured the accuracy of the data and analysis, reviewed the draft and approved the final version of the manuscript for submission. 
Fig 1: CONSORT 2010 Flow Diagram

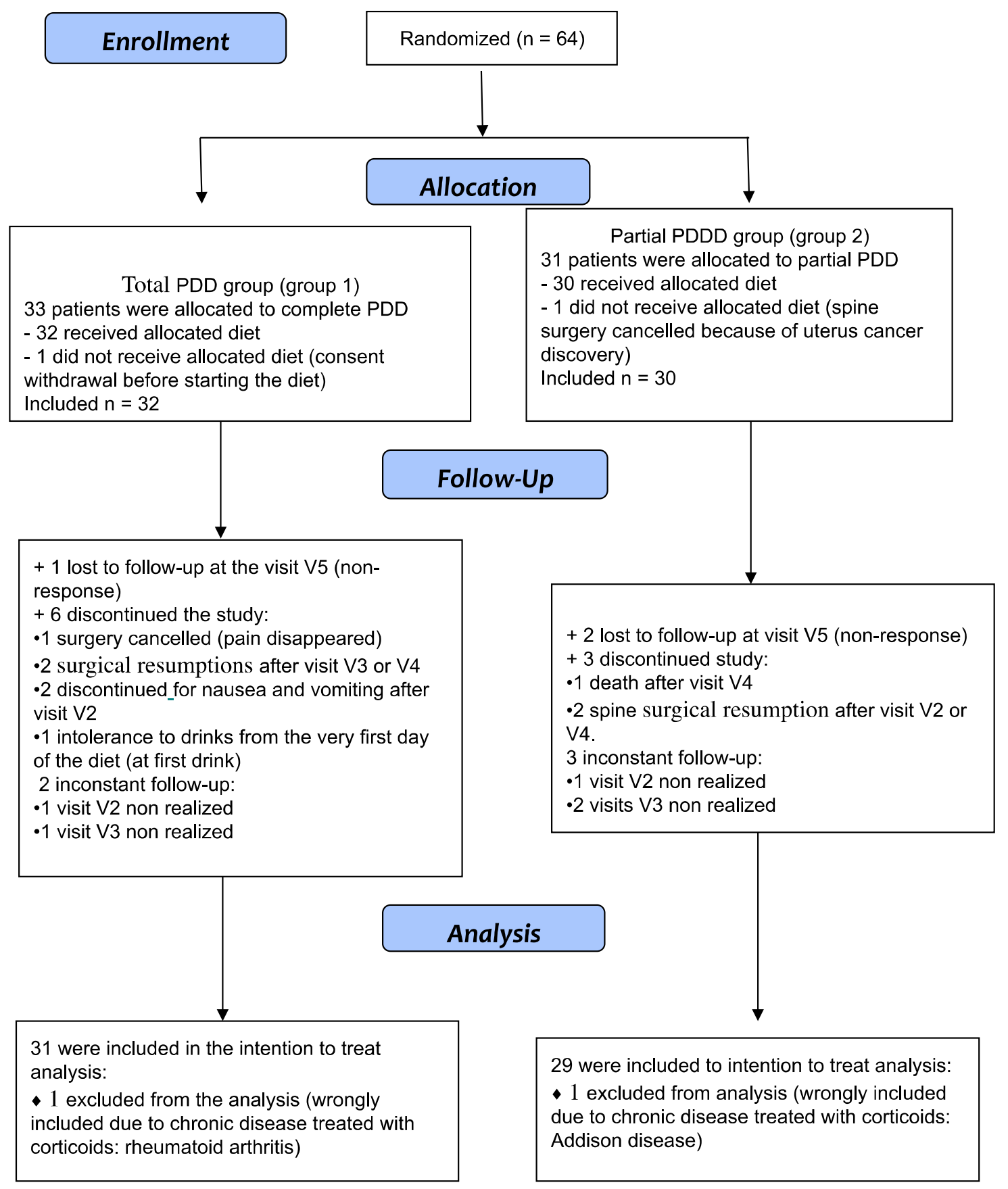


Fig 2:

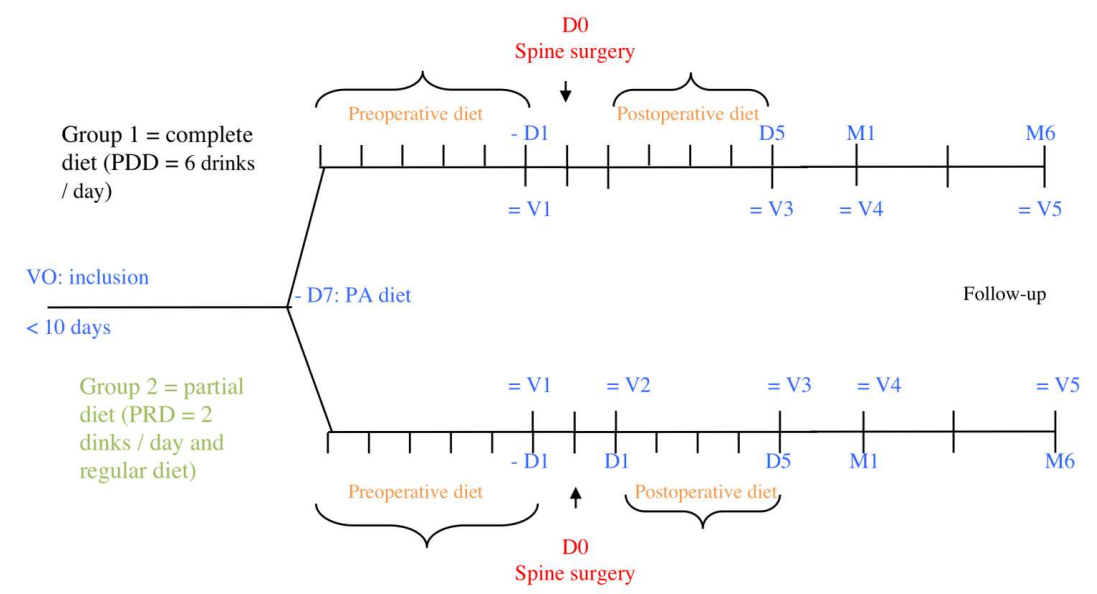

Page 22 sur 28 
Table 1:

\begin{tabular}{|c|c|c|}
\hline \multicolumn{2}{|r|}{ NUTRITION INFORMATION } & $250 \mathrm{ml}$ \\
\hline \multicolumn{2}{|l|}{ Energy } & $265 \mathrm{kcal}$ \\
\hline \multicolumn{2}{|l|}{ Proteins } & $10 \mathrm{~g}$ \\
\hline \multicolumn{2}{|c|}{ Carbohydrates } & $30 \mathrm{~g}$ \\
\hline \multicolumn{2}{|c|}{ Of which sugars } & $10 \mathrm{~g}$ \\
\hline \multicolumn{2}{|c|}{ Fats (total) } & $11 \cdot 25 \mathrm{~g}$ \\
\hline \multirow[t]{4}{*}{ Of which } & -saturated fatty acids (FA) & $3 \mathrm{~g}$ \\
\hline & - monounsaturated FA & $3 \cdot 3 \mathrm{~g}$ \\
\hline & - polyunsaturated FA & $2 \cdot 5 \mathrm{~g}$ \\
\hline & - omega 3 (total) & $1.8 \mathrm{~g}$ \\
\hline Fibers & & $4.5 \mathrm{~g}$ \\
\hline
\end{tabular}

\begin{tabular}{|c|c|c|c|}
\hline VITAMINS & $250 \mathrm{ml}$ & MINERALS & $250 \mathrm{ml}$ \\
\hline A & $135 \mu \mathrm{g}$ & Calcium & $152 \mathrm{mg}$ \\
\hline E & $11 \mathrm{mg}$ & Potassium & $281 \mathrm{mg}$ \\
\hline $\mathrm{D}$ & $1.8 \mu \mathrm{g}$ & Magnesium & $31 \mathrm{mg}$ \\
\hline $\mathrm{C}$ & $94 \mathrm{mg}$ & Sodium & $106 \mathrm{mg}$ \\
\hline B1 & $1 \cdot 1 \mathrm{mg}$ & Copper & $0.25 \mathrm{mg}$ \\
\hline B2 & $0.7 \mathrm{mg}$ & Iron & $0.3 \mathrm{mg}$ \\
\hline B6 & $2 \cdot 1 \mathrm{mg}$ & Manganese & $0.5 \mathrm{mg}$ \\
\hline PP & $4.2 \mathrm{mg}$ & Zinc & $1 \mathrm{mg}$ \\
\hline B5 & $2 \cdot 2 \mathrm{mg}$ & Chlorides & $265 \mathrm{mg}$ \\
\hline $\mathrm{H}$ & $42 \mu \mathrm{g}$ & Iodine & $7 \mu \mathrm{g}$ \\
\hline B9 & $111 \mu \mathrm{g}$ & Chromium & $25 \mu \mathrm{g}$ \\
\hline B12 & $0 \cdot 1 \mu \mathrm{g}$ & Molybdenum & $8.8 \mu \mathrm{g}$ \\
\hline K1 & $4.3 \mu \mathrm{g}$ & Selenium & $2 \cdot 5 \mu \mathrm{g}$ \\
\hline & & Phosphorus & $112 \mathrm{mg}$ \\
\hline & & Fluorine & $0.5 \mathrm{mg}$ \\
\hline
\end{tabular}


Table 2:

\begin{tabular}{|c|c|c|c|c|c|}
\hline & & $\begin{array}{l}\text { Mean } \pm \mathrm{SD}(\min - \\
\max )\end{array}$ & $\begin{array}{l}\text { Group 1 } \\
(\mathrm{n}=31)\end{array}$ & $\begin{array}{l}\text { Group 2 } \\
(\mathrm{n}=29)\end{array}$ & $P$ \\
\hline \multirow[t]{4}{*}{$\begin{array}{l}\text { Patient } \\
\text { characteristics }\end{array}$} & Age (yr.) & & $\begin{array}{l}59 \pm 13 \\
(32-79)\end{array}$ & $\begin{array}{l}54 \pm 11 \\
(32-85)\end{array}$ & NS \\
\hline & BMI $\left(\mathrm{kg} / \mathrm{m}^{2}\right)$ & & $\begin{array}{l}27.4 \pm 6.3 \\
(18.5-43.2)\end{array}$ & $\begin{array}{l}27.4 \pm 5.2 \\
(19.5-39.4)\end{array}$ & NS \\
\hline & Sex ratio $(\mathrm{F} / \mathrm{M})$ & & $20(65 \%) / 11(35 \%)$ & $\begin{array}{l}14(48 \%) / 15 \\
(52 \%)\end{array}$ & NS \\
\hline & $\begin{array}{l}\text { Median of duration of } \\
\text { pain before surgery (yr.) }\end{array}$ & & 2.5 & 2.0 & \\
\hline \multirow[t]{9}{*}{ Pain } & \multirow[t]{5}{*}{$\begin{array}{l}\text { Pain before inclusion } \\
\text { (V0) }\end{array}$} & At rest & $4.0 \pm 2.7(0-8)$ & $4.6 \pm 1.9(1-10)$ & NS \\
\hline & & $\begin{array}{l}\text { With walking } \\
\text { ( move m e } \mathrm{n} \mathrm{t}- \\
\text { evoked pain) }\end{array}$ & $6.7 \pm 2.5(0-10)$ & $6.8 \pm 2.1(1-10)$ & NS \\
\hline & & $\begin{array}{l}\text { Pain killer before } \\
\text { inclusion }\end{array}$ & $27(87 \%)$ & $24(83 \%)$ & NS \\
\hline & & $\begin{array}{l}\text { Neuropathic pain } \\
\text { from DN4 }\end{array}$ & $4.3 \pm 1.8(1-8)$ & $4.2 \pm 2.1(0-8)$ & NS \\
\hline & & $\begin{array}{l}\text { Neuropathic pain } \\
\text { from NPSI }\end{array}$ & $27.1 \pm 19.1(3-82)$ & $\begin{array}{l}32.3 \pm 17.1 \\
(6-65)\end{array}$ & NS \\
\hline & \multirow[t]{4}{*}{$\begin{array}{l}\text { Pain after diet and } \\
\text { before surgery (V1) }\end{array}$} & At rest & $3.5 \pm 2.5(0-8)$ & $4.5 \pm 2.4(0-10)$ & 0.144 \\
\hline & & $\begin{array}{l}\text { With walking } \\
\text { ( move me n t - } \\
\text { evoked pain) }\end{array}$ & $5.7 \pm 2.8(0-10)$ & $\begin{array}{l}6.6 \pm 2.2((2- \\
10)\end{array}$ & 0.166 \\
\hline & & $\begin{array}{l}\text { Neuropathic pain } \\
\text { from DN4 }\end{array}$ & $3.8 \pm 2.2(0-9)$ & $3.9 \pm 2.0(0-8)$ & NS \\
\hline & & $\begin{array}{l}\text { Neuropathic pain } \\
\text { from NPSI }\end{array}$ & $24.3 \pm 14.5(0-62)$ & $\begin{array}{l}29.1 \pm 16.2 \\
(0-60)\end{array}$ & NS \\
\hline \multirow[t]{8}{*}{ Quality of life } & \multirow[t]{4}{*}{ Before inclusion (V0) } & $\begin{array}{l}\text { Sleep disorder }(0 \\
\text { to } 10)\end{array}$ & $4.3 \pm 3.3(0-8)$ & $4.4 \pm 2.6(0-9)$ & NS \\
\hline & & $\begin{array}{l}\text { EIFEL } \\
\text { questionnaire }\end{array}$ & $14.3 \pm 4.6(4-22)$ & $\begin{array}{l}15.7 \pm 3.4 \\
(8-23)\end{array}$ & NS \\
\hline & & $\begin{array}{l}\text { Worst pain (BPI } \\
\text { questionnaire) }\end{array}$ & $7.8 \pm 1.9(4-10)$ & $8.4 \pm 1.6(5-10)$ & NS \\
\hline & & $\begin{array}{l}\text { Lowest pain (BPI } \\
\text { questionnaire) }\end{array}$ & $2.3 \pm 2.0(0-8)$ & $3.3 \pm 2.1(0-10)$ & NS \\
\hline & \multirow[t]{4}{*}{$\begin{array}{l}\text { After diet and before } \\
\text { surgery (V1) }\end{array}$} & $\begin{array}{l}\text { Sleep disorder }(0 \\
\text { to } 10)\end{array}$ & $4.0 \pm 3.1(0-9)$ & $4.5 \pm 2.7(0-9)$ & NS \\
\hline & & $\begin{array}{l}\text { EIFEL } \\
\text { questionnaire }\end{array}$ & $13.1 \pm 5.1(2-22)$ & $\begin{array}{l}15.5 \pm 3.6 \\
(7-22)\end{array}$ & 0.0465 \\
\hline & & $\begin{array}{l}\text { Worst pain (BPI } \\
\text { questionnaire) }\end{array}$ & $7.2 \pm 2.4(2-10)$ & $7.9 \pm 2.2(2-10)$ & NS \\
\hline & & $\begin{array}{l}\text { Lowest pain (BPI } \\
\text { questionnaire) }\end{array}$ & $1.9 \pm 2.0(0-7)$ & $2.7 \pm 2.6(0-10)$ & NS \\
\hline
\end{tabular}


Table 3 :

Compliance
\begin{tabular}{|c|c|c|c|}
\cline { 3 - 4 } & to the PA diet & Group 1 & Group 2 \\
\hline Preoperative period & 7 days & $100 \%(30 / 30)$ & $83 \%(24 / 29)$ \\
\hline $\begin{array}{c}\text { Postoperative period } \\
\text { (V2 to V3) }\end{array}$ & 5 days & $83 \%(20 / 24)$ & $80 \%(20 / 25)$ \\
\hline
\end{tabular}


Table 4:

\begin{tabular}{|c|c|c|c|c|}
\hline & & & & \\
\hline & Group 1 & Group 2 & $\mathrm{P}$ \\
\hline $\begin{array}{l}\text { Previous } \\
\text { surgery }\end{array}$ & Spine surgery & $9(29 \%)$ & $6(21 \%)$ & NS \\
\hline \multirow[t]{5}{*}{ Spine surgery } & Disc herniation & $1(3.2 \%)$ & $1(3.4 \%)$ & NS \\
\hline & $\begin{array}{l}\text { Facetectomy/ } \\
\text { laminarthrectomy } \\
\text { + without arthrodesis }\end{array}$ & $13(41.9 \%)$ & $10(34.4 \%)$ & NS \\
\hline & + with arthrodesis & $17(54.8 \%)$ & $18(62 \%)$ & NS \\
\hline & Duration of surgery (hr.) & $1.4 \pm 0.5(0.45-4.20)$ & $1.4 \pm 0.5(0.30-3.40)$ & $\mathrm{NS}$ \\
\hline & Hospital stay (day) & $5 \pm 2.3(5-?)$ & $4.8 \pm 1.3(5-3)$ & NS \\
\hline \multirow[t]{2}{*}{ Anesthesia } & $\begin{array}{l}\text { Sufentanil total dose } \\
(\mu \mathrm{g})\end{array}$ & $62.64 \pm 48.0(20-230)$ & $\begin{array}{l}56.81 \pm 33.70 \\
(15-160)\end{array}$ & NS \\
\hline & $\begin{array}{l}\text { Anesthesia (Propofol / } \\
\text { Sevoflurane) }\end{array}$ & $84 \% / 61 \%$ & $97 \% / 66 \%$ & \\
\hline
\end{tabular}


Table 5:

\begin{tabular}{|c|c|c|c|c|c|}
\hline & & \multirow[b]{2}{*}{$\begin{array}{l}\text { Mean } \pm \text { SD (min- } \\
\max )\end{array}$} & \\
\hline & & & Group 1 & Group 2 & $P$ \\
\hline \multirow[t]{8}{*}{ Pain } & \multirow{4}{*}{$\begin{array}{l}\text { Pain just after surgery } \\
\text { (V2) }\end{array}$} & At rest & $3.7 \pm 2.5(0-10)$ & $5.3 \pm 2.6(2-10)$ & 0.022 \\
\hline & & $\begin{array}{l}\text { With walking } \\
\text { ( } \mathrm{m} \text { ove me n } \mathrm{t}- \\
\text { evoked pain) }\end{array}$ & $5.1 \pm 2.9(0-10)$ & $6.3 \pm 2.6(2-10)$ & 0.138 \\
\hline & & $\begin{array}{l}\text { Neuropathic pain } \\
\text { (DN4) }\end{array}$ & $2.0 \pm 1.8(0-6)$ & $2.0 \pm 1.6(0-5)$ & NS \\
\hline & & $\begin{array}{l}\text { Neuropathic pain } \\
\text { from NPSI }\end{array}$ & $14.7 \pm 14.7(0-57)$ & $\begin{array}{l}21.2 \pm 16.9 \\
(0-65)\end{array}$ & NS \\
\hline & \multirow{4}{*}{$\begin{array}{l}\text { Pain at the end of diet } \\
\text { (V3) }\end{array}$} & At rest & $2.3 \pm 2.1(0-8)$ & $2.4 \pm 1.9(0-8)$ & NS \\
\hline & & $\begin{array}{l}\text { With walking } \\
\text { ( move me nt - } \\
\text { evoked pain) }\end{array}$ & $3.2 \pm 2.3(0-10)$ & $3.7 \pm 1.6((0-6)$ & NS \\
\hline & & $\begin{array}{l}\text { Neuropathic pain } \\
\text { from DN4 }\end{array}$ & $1.9 \pm 1.3(0-5)$ & $2.0 \pm 1.5(0-6)$ & NS \\
\hline & & $\begin{array}{l}\text { Neuropathic pain } \\
\text { from NPSI }\end{array}$ & $10.4 \pm 11.3(0-53)$ & $\begin{array}{l}14.4 \pm 11.6 \\
(0-36)\end{array}$ & NS \\
\hline \multirow[t]{8}{*}{ Quality of life } & \multirow[t]{4}{*}{ Just after surgery (V2) } & $\begin{array}{l}\text { Sleep disorder }(0 \\
\text { to } 10)\end{array}$ & $4.3 \pm 3.5(0-10)$ & $4.8 \pm 3.5(0-10)$ & NS \\
\hline & & $\begin{array}{l}\text { EIFEL } \\
\text { questionnaire }\end{array}$ & na & na & \\
\hline & & $\begin{array}{l}\text { Worst pain (BPI } \\
\text { questionnaire) }\end{array}$ & na & na & \\
\hline & & $\begin{array}{l}\text { Lowest pain (BPI } \\
\text { questionnaire) }\end{array}$ & na & na & \\
\hline & \multirow[t]{4}{*}{ At the end of diet (V3) } & $\begin{array}{l}\text { Sleep disorder }(0 \\
\text { to } 10)\end{array}$ & $2.7 \pm 2.9(0-10)$ & $2.6 \pm 2.5(0-8)$ & NS \\
\hline & & \begin{tabular}{|l} 
EIFEL \\
questionnaire
\end{tabular} & $12.1 \pm 5.7(0-24)$ & $15.0 \pm 4.7(7-23)$ & 0.0629 \\
\hline & & $\begin{array}{l}\text { Worst pain (BPI } \\
\text { questionnaire) }\end{array}$ & $6.9 \pm 2.0(3-10)$ & $7.6 \pm 2.1(3-10)$ & NS \\
\hline & & $\begin{array}{l}\text { Lowest pain (BPI } \\
\text { questionnaire) }\end{array}$ & $1.4 \pm 2.0(0-8)$ & $1.7 \pm 1.3(0-4)$ & NS \\
\hline
\end{tabular}


Table 6:

\begin{tabular}{|c|c|c|c|}
\hline $\begin{array}{l}\text { Morphine consumption } \\
\text { (mg) }\end{array}$ & $\begin{array}{l}\text { Mean } \pm \text { SD }(\text { min- } \\
\max )\end{array}$ & Group 1 & Group 2 \\
\hline \multirow[t]{2}{*}{ Intravenously } & $\begin{array}{l}\text { Initial titration in } \\
\text { ICU }\end{array}$ & $8.9 \pm 4.2(2-18)$ & $10.0 \pm 5.5(2-29)$ \\
\hline & PCA at D0 & $25.0 \pm 19.0(2.1-76)$ & $19.8 \pm 15.4(2-67)$ \\
\hline \multirow[t]{6}{*}{ Oral administration } & D1 & $23.3 \pm 15.3(10-40)$ & $29 \pm 23.8(10-80)$ \\
\hline & $\mathrm{D} 2$ & $36.7 \pm 24.2(10-80)$ & $30.0 \pm 23.3(10-80)$ \\
\hline & $\overline{\mathrm{D} 3}$ & $26.9 \pm 24.2(5-80)$ & $27.0 \pm 23.2(10-80)$ \\
\hline & D4 & $30.0 \pm 21.2(10-60)$ & $30.0 \pm 26.1(10-80)$ \\
\hline & $\overline{\mathrm{D} 5}$ & $35.0 \pm 7.1(30-40)$ & $40.0 \pm 36.1(10-80)$ \\
\hline & D6 & $35.0 \pm 7.1(30-40)$ & $60.0 \pm 28.3(40-80)$ \\
\hline Total dose & & $134.5 \pm 121.5(24-487)$ & $134.6 \pm 109.2(6-561)$ \\
\hline
\end{tabular}

